\title{
Receptor Tyrosine Kinase Gene Rearrangement
}

National Cancer Institute

\section{Source}

National Cancer Institute. Receptor Tyrosine Kinase Gene Rearrangement. NCI

Thesaurus. Code C156028.

A molecular abnormality indicating rearrangement of a receptor tyrosine kinase family gene. 